\title{
ÁLTALÁNOSÍTOTT THURSTONE-MÓDSZER ALKALMAZÁSOKKAL
}

\author{
MIHÁLYKÓNÉ ORBÁN ÉVA, MIHÁLYKÓ CSABA, KAJTÁR PATRIK
}

\begin{abstract}
Publikációnkban egy páros összehasonlítási módszert mutatunk be, amely segítségével több döntési kategóriát megengedve tudjuk elemezni az összehasonlítási eredményeket. A cikkben példát is mutatunk az alkalmazásra, amely során női teniszcsillagok rangsorát állítjuk fel egymás ellen játszott mérkőzéseik alapján.
\end{abstract}

\section{Bevezetés}

Páros összehasonlításokat gyakran alkalmaznak a döntéselméletben objektumok összehasonlításakor abban az esetben, ha az összehasonlítás kritériuma valamilyen nehezen skálázható szubjektív szempont. Számos példát tartalmaz az alkalmazásra például [10] és az általa hivatkozott publikációk. Magyar kutatók is intenzíven foglalkoznak a területtel [2].

A páros összehasonlítási módszerek két fő csoportba sorolhatók. Az egyikbe tartozók páros összehasonlítás mátrixon alapulnak. A mátrix $a_{i, j}$ eleme úgy interpretálandó, hogy az $i$-edik és a $j$-edik objektum összehasonlításakor az $i$-edik elem „hányszorosan” jobb, mint a $j$-edik. A módszert Saaty dolgozta ki, és AHP néven ismert [9]. A kiértékelés leggyakrabban használt módszere a sajátvektor módszer. Ennek előnye a könnyü kivitelezhetőség, valamint az, hogy a koordináták súlyokként is értelmezhetők, ezáltal többszintű döntést tesznek lehetővé. Hátránya, hogy ilyen formájában csak teljes összehasonlítás esetén müködik, valamint az objektumok egyenlőségének tesztelése nem kidolgozott. Nem teljes összehasonlítás esetén is múködő módszer például a logaritmikus legkisebb négyzetek módszere (LLSM), amely egy optimalizációs problémához vezet, s egy lineáris egyenletrendszer megoldását igényli. [2]-ben a szerzők szükséges és elégséges feltételt fogalmaznak meg LLSM alkalmazásakor nemteljes összehasonlítás esetére a paraméterek egyértelmü meghatározására.

A másik gyakran alkalmazott eljárás során az értékelendő objektumok mögé egy-egy látens valószínűségi változót képzelnek, és az értékelés során a valószínűségi változók különbségéről döntenek. A látens valószínüségi változók eloszlásának különbségére Thurstone normális eloszlást javasolt, de a leggyakrabban 
logisztikus eloszlást használnak [3]. Legtöbbször két kategóriát engednek meg (jobb/rosszabb), azonban a mögöttes gondolatmenet általánosítható több döntési kategóriára is. Döntetlent is megenged pl. [8], illetve több kategóriát is alkalmaz [1]. Széleskörü áttekintést ad a látens valószínüségi változókkal kapcsolatos modellekről [4]. A leggyakrabban alkalmazott megoldási módszer ezen modellek esetén az, hogy a paraméterekre egy lineáris egyenletrendszert állítanak fel, amelynek egyik oldalán a kategóriák becsült valószínüségeinek valamely függvénye áll. $\mathrm{Az}$ eredmények közti inkonzisztencia az egyenletrendszer pontos megoldását általában nem teszi lehetővé, csak a megoldás legkisebb négyzetek módszerével történő közelítését. A megoldást többnyire abban az esetben adják meg, amikor minden objektum minden más objektummal össze van hasonlítva. A becsült paraméterek egyértelmű létezése a valószínüségek függvényének képezhetőségétől is függ, megoldhatóságra vonatkozó tételek több kategória megengedése esetén nem találhatók. A hiányzó összehasonlításokból adódó problémákat [4] külön megemlíti.

Mi visszanyúlunk Thurstone eredeti gondolatához. Normális eloszlású látens valószínüségi változókat feltételezünk, az objektumok sorrendjének a várható értékek sorrendjét tekintjük. Több döntési kategóriát is megengedünk. Az egyes kategóriák bekövetkezésének valószínüségeit a paraméterek függvényében felírjuk. A paramétereket maximum likelihood (ML) becsléssel becsüljük. Ez a becslési módszer nemteljes összehasonlítások esetén is természetes módon müködik. Publikációnkban bemutatjuk az általános modellt, és néhány esetben elégséges feltételt adunk az ML-becslés létezésére és egyértelmüségére. Az ML-becslések aszimptotikus normalitása alapján a várható értékekre konfidenciaintervallumok konstruálhatók. Az ML-becslések további előnye, hogy hozzájuk kapcsolódóan a hipotézisvizsgálatok is kidolgozottak. Emellett a várható értékek súlyokká konvertálhatók, így lehetővé válik többszintü döntések kivitelezése is.

\section{Az általános modell}

Legyen a rangsorolandó objektumok száma $n$, jelöljük őket $1,2, \ldots, n$-nel. Az $i$-edik objektumhoz tartozó látens valószínüségi változó legyen $\xi_{i}, i=1,2, \ldots, n$. A lehetséges döntési kategóriák száma legyen $s \quad(2 \leq s)$, és a döntéseket jelölje $C_{1}, C_{2}, \ldots, C_{s}$. Ezek egymást páronként kizárják. Nekik megfelelően a valós számok halmazát $s$ darab diszjunkt részintervallumra $\left(I_{k}, k=1,2, \ldots, s\right)$ osztjuk, $I_{j} \cap I_{k}=\oslash$, ha $j \neq k$ és $\mathbb{R}=I_{1} \cup I_{2} \cup \ldots \cup I_{s}$. Ha az $i$-edik és a $j$-edik objektum összehasonlításánál a döntés $C_{k}$, akkor $\xi_{i}-\xi_{j} \in I_{k}$. Feltételezzük, hogy $\xi_{i} \sim N\left(m_{i}, \sigma^{2}\right), i=1,2, \ldots, n$ független valószínüségi változók. Ezzel a feltételezéssel más publikációkban is találkozhatunk. Az $m_{i}, i=1,2, \ldots, n$ várható értékek sorrendje adja meg az objektumok sorrendjét.

Az általánosság további korlátozása nélkül feltételezhetö, hogy $\sigma=\frac{1}{\sqrt{2}}$. Ekkor a döntések az $\eta_{i, j}=\xi_{i}-\xi_{j} \sim N\left(m_{i}-m_{j}, 1\right), i=1, \ldots, n-1, j=i+1, \ldots, n$ valószínüségi változókról szólnak. A különbségekre független megfigyeléseket tételezünk fel. 
Jelölje $A_{i, j, k}$ azt a számot, ahány döntés a $C_{k}$ kategóriát jelöli meg az $i$. és a $j$. objektum összehasonlítása során, és álljon az $A$ háromdimenziós mátrix az $A_{i, j, k}$, $i=1,2, \ldots, n-1, j=i+1, \ldots, n, k=1,2, \ldots, s$ elemekböl. Az intervallumokat meghatározzák a végpontjaik, ezeket jelöljük az alábbi módon:

$$
-\infty=a_{0}<a_{1}<a_{2}<\ldots<a_{s-1}<a_{s}=\infty .
$$

Használva a $\Phi(-\infty)=0$ és $\Phi(\infty)=1$ megfeleltetést, ahol $\Phi$ a standard normális eloszlásfüggvény, a likelihood függvény az alábbi:

$$
\begin{gathered}
L\left(A \mid m_{1}, \ldots, m_{n}, I_{1}, \ldots, I_{s}\right)=L\left(A \mid m_{1}, \ldots, m_{n}, a_{1}, \ldots, a_{s-1}\right)= \\
\prod_{k=1}^{s} \prod_{i=1}^{n-1} \prod_{j=i+1}^{n}\left(\Phi\left(a_{k}-\left(m_{i}-m_{j}\right)\right)-\Phi\left(a_{k-1}-\left(m_{i}-m_{j}\right)\right)\right)^{A_{i, j, k}},
\end{gathered}
$$

amit $m=\left(m_{1}, \ldots, m_{n}\right)$-ben valamint $\left(a_{1}, \ldots, a_{s-1}\right)$-ben maximalizálva kapjuk a paraméterek maximum likelihood becslését.

A modellben természetes módon feltételezzük a szimmetriát, azaz $a_{i}=-a_{s-i}$, $i=1,2, \ldots,[s / 2]$. A becsült várható értékekből exponenciális transzformáció és normálás után súlyok képezhetők. A várható értékek azonosságának tesztelésére a likelihood hányados próba alkalmazható. A becslések létezésére és egyértelmüségére a következő fejezetben speciális esetekben elégséges feltételeket adunk.

\section{Speciális esetek}

Ebben a fejezetben a legfontosabb speciális eseteket mutatjuk be, és ezekben elégséges feltételt adunk az ML-becslés létezésére és egyértelmüségére. Ennek kulcsmotívuma egy gráf összefüggősége, amelyben a csúcsok mindig az értékelendő objektumok, az élek viszont más-más feltételek teljesülése esetén vannak behúzva. Példát említünk arra, amikor a modell természetes módon használható.

1. A klasszikus Thurstone-modell - jobb/rosszabb opciók esete: $s=2$

Ebben az esetben két kategória van a döntésre, a jobb és a rosszabb, ami két intervallumot jelent az $a_{1}=0$ ponttal elválasztva. Az ML-becslés létezésével és egyértelmüségével kapcsolatban az alábbi állítást bizonyítottuk:

3.1. TÉTEL. Definiáljuk a $G R_{2}$ gráfot a következőképpen: az $i$. és j. objektum akkor legyen összekötve, ha $0<A_{i, j, 1} \cdot A_{i, j, 2}$. Legyen $m_{1}=0$. Ha a $G R_{2}$ gráf összefüggö, akkor (1)-nek létezik maximuma, és a maximumhely egyértelmü.

Ezt a modellt alkalmaztuk gyártási hibák összehasonlításánál [5].

2. Jobb, egyforma, rosszabb opciók esete: $s=3$ 
Ebben az esetben az $i$. és a $j$. objektumot egyformának tekintjük, ha a látens valószínüségi változók egymástól való eltérése nem halad meg egy bizonyos szintet. A számegyenes 3 részre van osztva, a szimmetria miatt egy osztópont bevonása és becslése szükséges. Az ML-becslés létezésével és egyértelmüségével kapcsolatban az alábbi állítást bizonyítottuk [7]:

3.2. TÉtel. Legyen $s=3$ vagy $s=4$. Tegyük fel, hogy valamely $i_{1}<j_{1}$ esetén $0<A_{i_{1}, j_{1}, k}$, valamely $1<k<s$ esetén. Továbbá tegyük fel, hogy valamely $i_{2}<j_{2}$ esetén $0<A_{i_{2}, j_{2}, k}$, és $0<A_{i_{2}, j_{2}, l}$ fennáll valamely $|k-l|>1$ pár esetén. Legyen a $G R_{3}$ gráf az alábbi módon definiálva: az $(i, j) i<j$ csúcspár akkor van összekötve, ha $0<A_{i, j, k}$ valamely $k=2,3, . ., s-1$ esetén, vagy $0<A_{i, j, 1} \cdot A_{i, j, s}$. Rögzítsük az $m_{1}=0$ értéket. Ha a $G R_{3}$ gráf összefüggő, akkor az (1) likelihood függvény maximuma létezik és egyértelmü.

A modell jól alkalmazható olyan sportágak esetében, ahol döntetlennel vagy győzelemmel, vereséggel végződhetnek a mérkőzések. Müködik nem teljes összehasonlítások esetén is, így olyan játékosok rangsora is elkészíthető, akik között voltak olyanok is, akik soha nem játszottak egymás ellen.

3. Sokkal jobb, jobb, rosszabb, sokkal rosszabb opciók esete: $s=4$

Ebben az esetben az egyforma nem megengedett, viszont ha a különbség abszolút értéke meghalad egy szintet, akkor az egyik objektumot sokkal jobbnak/sokkal rosszabbnak tekintjük a másiknál. Ebben az esetben a szimmetria miatt a három osztópont egy paraméterrel megadható. Az ML-becslés létezésével és egyértelmüségével kapcsolatos tétel megegyezik a 3.2 tétellel $s=4$ esetén. A módszer jól alkalmazható például olyan sportágak esetén, ahol döntetlen ugyan nem lehet a mérkőzések kimenetele, de nagy győzelem, vagy súlyos vereség definiálható. Ilyen sportág lehet például a tenisz. A jobb/sokkal jobb besorolást itt és más esetekben is a terület szakértőire lehet bízni. Példát a 4. fejezetben mutatunk.

4. Sokkal jobb, jobb, egyforma, rosszabb, sokkal rosszabb opciók esete: $s=5$

Ebben az esetben két objektum egyforma, ha a látens valószínüségi változók különbsége abszolút értékben nem halad meg egy szintet. Ha azonban egy ennél nagyobb szintet is meghalad, akkor sokkal jobb/sokkal rosszabb értékelés alakul ki. A 4 osztópont két $a_{i}$ változó bevezetését igényli. A likelihood függvény maximumának létezésével és egyértelmüségével kapcsolatban az alábbi tételt bizonyítottuk:

3.3. TÉtel. Tegyük fel, hogy valamely $i_{1}<j_{1}$ esetén $0<A_{i_{1}, j_{1}, 3}$, valamint valamely $i_{2}<j_{2}$ esetén $0<A_{i_{2}, j_{2}, 2}$, vagy $0<A_{i_{2}, j_{2}, 4}$, továbbá valamely $i_{3}<j_{3}$ esetén $0<A_{i_{3}, j_{3}, 1}$, és $0<A_{i_{3}, j_{3}, 5}$ fennáll. Legyen a $G R_{5}$ gráfban az $(i, j) i<j$ csúcspár összekötve, ha $0<A_{i, j, 3} \cdot A_{i, j, k}$ valamely $k=1,2,4,5$ esetén, vagy $0<A_{i, j, 2} \cdot A_{i, j, 4}$, vagy $0<A_{i, j, 1} \cdot A_{i, j, 4}$, vagy $0<A_{i, j, 2} \cdot A_{i, j, 5}$. Ha a $G R_{5}$ gráf összefüggő, akkor $m_{1}=0$ rögzítése után az (1) likelihood függvény maximuma létezik és egyértelmü. 
A modellt alkalmaztuk fényforrások összehasonlítása esetén és a kapott eredményeket publikáltuk a [6] publikációban.

\section{Alkalmazás}

Most mutatunk egy egyszerü alkalmazást $s=4$ esetén női tenisz világklasszisok összehasonlítására. Kiemelkedő női tenisz játékosok voltak, a világranglistát is vezették a következő személyek: Chris Evert (\#1), Steffi Graf (\#2), Martina Navratilova (\#3), Szeles Mónika (\#4) és Serena Williams (\#5). A női tornákon többnyire olyan mérkőzéseket játszanak, ahol az eredmények 2:0, 2:1, 1:2 vagy 0:2. Ezeket tekintettük a 4 kategóriának. Az 5 teniszező egymás ellen játszott ATPmérkőzéseinek végeredményeit a http://www.wtatennis.com/head2head/ honlapról töltöttük le. Az egymás elleni eredményeket az 1. táblázat első fele tartalmazza. A meccsek eredményei azt mutatják, hogy Szeles Navratilova kivételével mindenkinél gyengébb, viszont Navratilova jobb, mint Evert és jobb, mint Graf. Így az egymás elleni eredmények inkonzisztensek, nem adnak könnyen megállapítható sorrendet. Bár nem mindenki játszott mindenkivel, de az ML-becslés létezésének és egyértelmüségének feltételei könnyen láthatóan teljesülnek. A likelihood függvényt numerikusan optimalizáltuk, és a várható értékek ML-becslésére sorrendben az alábbi eredményeket kaptuk: $\widehat{m}_{5}=0,374, \widehat{m}_{3}=0,084, \widehat{m}_{2}=0,066, \widehat{m}_{1}=0$, $\widehat{m}_{4}=-0,067$. A belölük $w_{i}=\exp \left(\widehat{m}_{i}\right) / \sum_{j=1}^{5} \exp \left(\widehat{m}_{j}\right)$ transzformációval kialakított súlyvektor $\underline{w}=(0,180,0,193,0,196,0,169,0,262)$. Az egymás elleni eredmények becsült valószínúségeit az 1. táblázat második fele tartalmazza.

\begin{tabular}{|c|c||c|c|c|c||c|c|c|c|c|}
\hline \multicolumn{2}{|c||}{ Játékosok } & \multicolumn{4}{c||}{ Az eredmények } & \multicolumn{5}{c|}{ A becsült valószínüségek } \\
\hline „A" & „B" & $2: 0$ & $2: 1$ & $1: 2$ & $0: 2$ & $2: 0$ & $2: 1$ & $1: 2$ & $0: 2$ & „A" gyöz \\
\hline 1 & 2 & 6 & 0 & 1 & 6 & 0,289 & 0,185 & 0,190 & 0,336 & 0,474 \\
\hline 1 & 3 & 23 & 14 & 13 & 30 & 0,283 & 0,184 & 0,191 & 0,342 & 0,467 \\
\hline 1 & 4 & 2 & 0 & 1 & 0 & 0,336 & 0,191 & 0,184 & 0,289 & 0,527 \\
\hline 1 & 5 & 0 & 0 & 0 & 0 & 0,194 & 0,160 & 0,192 & 0,454 & 0,354 \\
\hline 2 & 3 & 4 & 5 & 3 & 6 & 0,306 & 0,187 & 0,189 & 0,318 & 0,493 \\
\hline 2 & 4 & 5 & 5 & 2 & 3 & 0,361 & 0,192 & 0,180 & 0,267 & 0,553 \\
\hline 2 & 5 & 0 & 1 & 1 & 0 & 0,212 & 0,167 & 0,193 & 0,428 & 0,379 \\
\hline 3 & 4 & 4 & 3 & 5 & 5 & 0,367 & 0,193 & 0,179 & 0,261 & 0,560 \\
\hline 3 & 5 & 0 & 0 & 0 & 0 & 0,218 & 0,168 & 0,193 & 0,421 & 0,386 \\
\hline 4 & 5 & 0 & 1 & 2 & 2 & 0,176 & 0,154 & 0,190 & 0,480 & 0,330 \\
\hline
\end{tabular}

1. táblázat. Az egymás elleni eredmények és a becsült valószínüségek. 
Összefoglalva elmondhatjuk, hogy szigorúan csak az egymás elleni mérkőzések eredményeit figyelembe véve, a bemutatott módszerrel elvégezve a kiértékelést, a vizsgált női teniszklasszisok sorrendje Williams, Navratilova, Graf, Evert és Szeles. Összehasonlításképpen megemlítjük, hogy a [2]-ben vizsgált LLSM segítségével kiértékelve az eredményeket, a páros összehasonlítás mátrixba a nyert és vesztett meccsek arányát írva, a $\underline{w}^{L L S M}=(0,149,0,222,0,153,0,133,0,343)$ súlyokhoz jutunk. Így a játékosok rangsora Williams, Graf, Navratilova, Evert, Szeles. Tehát a két módszer mind súlyokban, mind sorrendben különböző eredményt szolgáltat.

\section{Köszönetnyilvánítás}

A szerzők köszönetüket fejezik ki az EFOP-3.6.1-16-2016-00015. számú projekt anyagi támogatásáért.

\section{Hivatkozások}

[1] Agresti, A.: Analysis of ordinal paired comparison data, Applied Statistics, Vol. 41 No. 2, pp. 287-297 (1992). 10.2307/2347562

[2] BozókI, S., FülÖP, J., AND RónyAI, L.: On optimal completion of incomplete pairwise comparison matrices, Mathematical and Computer Modelling, Vol. 52 No. 1, pp. 318-333 (2010). DOI: 10.1016/j.mcm.2010.02.047

[3] Bradley, R. A. ANd Terry, M. E.: Rank analysis of incomplete block designs: I. The method of paired comparisons, Biometrika, Vol. 39 No. 3/4, pp. 324-345 (1952). DOI: 10.1093/biomet/39.3-4.324

[4] Cattelan, M.: Models for paired comparison data: A review with emphasis on dependent data, Statistical Science, Vol. 39 No. 3/4, pp. 412-433 (2012). DOI: 10.1214/12-STS396

[5] Orbán-Minálykó, É., Bognár, F., És Mihálykó, C.: Meghibásodások kockázati tényezőinek statisztikai kiértékelése szubjektív vélemények alapján, A karbantartás új szerepe címü nemzetközi konferencia kiadványa, pp. 161-173 (2016).

[6] Orbán-Mihálykó, É., Koltay, L., Szabó, F., Csuti, P., Kéri, R., and SchanDA, J.: A New Statistical Method for Ranking of Light Sources based on Subjective Points of View, Acta Polytechnica Hungarica, Vol. 12 No. 8, pp. 195-214 (2015). DOI: 10.12700/APH.12.8.2015.8.11

[7] Orbán-Minálykó, É., Mihálykó, C., And Koltay, L.: Generalization of the Thurstone method for multiple choices and incomplete paired comparisons, Central European Journal of Operations Research, Vol. 27, No. 1, pp. 133-159 (2019). DOI: 10.1007/s10100-017-04956

[8] Rao, P. V. And Kupper, L. L.: Ties in paired-comparison experiments: A generalization of the Bradley-Terry model, Journal of the American Statistical Association, Vol. 62 No. 317, pp. 194-204 (1967). DOI: 10.2307/2282923

[9] SAAty, T. L.: How to make a decision: the analytic hierarchy process, European Journal of Operational Research, Vol. 48 No. 1, pp. 9-26 (1990). DOI: 10.1016/0377-2217(90)90057-I

[10] Ureña, R., Chiclana, F., Morente-Molinera, J. A., and Herrera-Viedma, E.: Managing incomplete preference relations in decision making: a review and future trends, Information Sciences, Vol. 302, pp. 14-32 (2015). DOI: 10.1016/j.ins.2014.12.061 


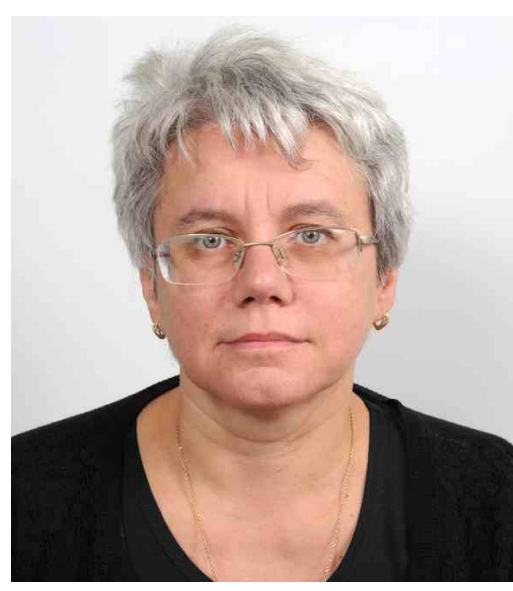

Dr. Mihálykóné dr. Orbán Éva 1964-ben született Pápán. 1987-ben végzett az Eötvös Loránd Tudományegyetemen okleveles matematikusként. 1991-ben egyetemi doktori címet szerzett a Veszprémi Egyetemen, majd 2004-ben $\mathrm{PhD}$-fokozatot informatika tudományterületen a Pannon Egyetemen. 1987 óta dolgozik Veszprémben a Pannon Egyetemen, illetve jogelődjein, jelenleg a Matematika Tanszéken egyetemi docensként. Kutatási területei: kockázati folyamatok, döntéselmélet, sztochasztikus modellezés. 60 tudományos közleménye jelent meg, közülük 27 folyóiratcikk, melyekre összességében 90 független hivatkozást kapott.

\section{MIHÁLYKÓNÉ ORBÁN ÉVA}

Pannon Egyetem

Matematika Tanszék

8200 Veszprém, Egyetem u. 10.

orbane@almos.uni-pannon.hu

Mihálykó Csaba arcképe és életrajza a szám egy másik cikkénél jelenik meg, mely cikknek szintén szerzője.

\section{MIHÁLYKÓ CSABA}

Pannon Egyetem

Matematika Tanszék

8200 Veszprém, Egyetem u. 10.

mihalyko@almos.uni-pannon.hu

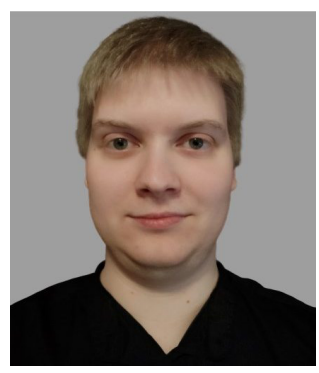

Kajtár Patrik mérnökinformatikusként végzett a veszprémi Pannon Egyetemen (2017), majd ugyanitt elvégezte a mérnökinformatikus MSc-képzést is egy évvel később (2018). Eközben szoftverfejlesztő mérnökként, majd projektmenedzserként dolgozott a veszprémi Continentalnál. Jelenleg vezetés és szervezés mesterszakot végez a Pannon Egyetemen és projektmenedzserként dolgozik a budapesti AIMotive-nál, ahol mesterséges intelligencia gyorsító chip kutatás-fejlesztési projektjeit vezeti.

\section{KAJTÁR PATRIK}

Pannon Egyetem

Matematika Tanszék

8200 Veszprém, Egyetem u. 10.

kajtarpatrik96@gmail.com 


\section{A GENERALIZATION OF THE THURSTONE METHOD WITH APPLICATIONS}

\section{Éva Orbán-Mihálykó, Csaba Mihálykó, Patrik Kajtár}

In this paper we present a generalization of Thurstone's method for multiple choices. We apply the maximum likelihood method for the estimation of the parameters. In special cases we present sufficient conditions for the existence and uniqueness of the maximizer. We also present practical cases for the applications and we also present an example for the evaluation of female tennis players' results.

Keywords: paired comparison, Thurstone method, maximum likelihood estimation, testing hypotheses, confidence interval.

Mathematics Subject Classification (2000): 62J15, 62H15. 